\title{
Financing Type and Sustainability Reporting: Financial Performance as Mediating Variable
}

\author{
Falikhatun $^{1 \bowtie}$, Salamah Wahyuni ${ }^{2}$, Milananda Ainun Niswah ${ }^{3}$ \\ and Afifah Oki Nilasakti ${ }^{4}$ \\ 1,2,3,4Fakultas Ekonomi dan Bisnis Universitas Sebelas Maret \\ Jl. Ir Sutami No.36A, Jebres, Kec. Jebres, Kota Surakarta, Jawa Tengah 57126 \\ DOI: http://dx.doi.org/10.15294/jda.v12i1.24930
}

Submitted: May $5^{\text {th }}, 2019$ Revised: September $15^{\text {th }}, 2019$ Accepted: January $20^{\text {th }}, 2020$ Published: March $31^{\text {th }}, 2020$

\begin{abstract}
The research aims to examine the effect of financing types on sustainability reporting with financial performance as a mediating variable. Independent variables in this study are represented by $\mathrm{Mu}-$ rabahah Musyarakah, and Mudharabah financing, while the mediating variable in this research is financial performance measured using Capital Adequacy Ratio (CAR) as a proxy. The Population of this research is Islamic Banking listed in statistical of Otoritas Jasa Keuangan Indonesia and published sustainability reporting and annual reports for the 2014-2017 period. The result of this study concluded that Financing Type proxied with Murabahah financing affects financial performance (CAR), and financial performance (CAR) also affects the Sustainability Reporting. The other proxies of financing type (Musyarakah and Mudharabah) do not affect financial performance. This study also concluded that financial performance variable mediates the effect of Financing type (Murabahah) on Sustainability Reporting.
\end{abstract}

Keywords: financing type, financial performance, sustainability reporting

How to cite (APA 6th Style)

Falikhatun, F., Wahyuni, S., Niswah, M., \& Nilasakti, A. (2020). Financing Type And Sustainability Reporting: Financial Performance As Mediating Variable. Jurnal Dinamika Akuntansi, 12(1), 3445. doi:https://doi.org/10.15294/jda.v12i1.24930

\section{INTRODUCTION}

Sustainability Reporting is a disclosure of a report that reflects organization performance in economic, social, environmental dimensions (the Association of Chartered Certified, 2014). Sustainability Reporting is also a form of firm interest in the environment and social condition which will have a positive effect on the development and the sustainability of the firm. Sustainability Reporting is used as a media to inform firm performance which consists of three aspects social, economic, and environmental to its stakeholder (Bellucci, Manetti, \& Thorne, 2018). Stakeholder's interest demands a firm to perform the activities toward the triple bottom line which includes economy, community, and environment as well as communicating performance in the form of sustainable reporting. Stakeholder's interests forced firms to perform activities that lead to the triple bottom line which consists of economy, community, and environment as well as communicating the performance in the sustainable report. Sustainability Reporting in Indonesia is compulsory, both separated from the annual report or combined with the annual report (Financial Service

author $(\square)$

E-mail: falie.feuns17@gmail.com 
Authority 2018). However, according to OJK statistics (2017), only 9\% of firms listed in Jakarta Stock Exchange (IDX) and published Sustainability Reporting. This indicates the low awareness of firms to publish Sustainability Reporting so that they need to be encouraged to increase the number of firms that publish the sustainable reporting according to the transparency and accountability principles (Ernest and Young, 2017).

Global Reporting Initiative develops GRI Standard that becomes a guideline for sustainability reporting with several indicators that have to be disclosed. However, this standard has limitations because it is only used for conventional firms (Haniffa, 2002), which then result in Islamic Social Reporting (ISR) as a concept based on the Islamic Social Reporting Index. This index is based on Accounting and Auditing Organizations for Islamic Financial Institution (AAOIFI) developed by previous researchers and adjusted to sharia principles based on al-Quran and al-Hadits.

The development of Islamic finance in the world, especially sharia banking, is experiencing rapid growth. This is marked by the significant increase in total assets globally in 2014-2017, sharia banking contributes $71 \%$ to Islamic finance (Worldbank, 2015). This enables sharia banks to improve their information transparency disclosed to the public in the form of Sustainability Reporting. With the disclosure of the Sustainability Report, it is expected that sharia banking will show its accountability and transparency to the ummah (fellow Muslim) and Allah SWT. Sustainability Reporting should be based on tauhid, that is accepting that Allah SWT is the owner of everything on earth and universe and human have to be responsible to Allah SWT (QS. 57:5). Therefore, the firm has a responsibility to Allah SWT, stakeholders, and the environment at once. For stakeholders, a firm is responsible to disclose their business activities for the benefit of the Ummah by promoting divine pleasure and making the Al-Quran and al-Hadith a guide in the implementation of operational activities of the company (Muhamad \& Noordin, 2014).

Antonio (2001), explains that sharia banking has two functions: as manager of investment and as a provider of financial services as well as a social service function. Sharia banking concept requires sharia banks to perform social services, through various financing scheme such as Qardh and qardhul hasan (kindness loan), zakat, Infaq dan Shadaqah as well as other forms of social funds following Islamic teaching. Sharia banking concept also requires banks to play a role in the development of human resources and donating funds for environmental maintenance and development. Law No. 21 of 2008 concerning sharia banking reaffirms the social function of sharia banking. Article 4 mentions that besides having a responsibility to collect and distribute public funds, sharia banks and sharia business unit can perform social functions in the form of baitul maal, receiving funds from zakat, donations, alms, grants or other social funds and distribute it to an organization that manages zakat (Dewi and Widagdo, 2003).

Sustainability Reporting is affected by the budget available to implement it and one of the factors that affect the budget is a risk. In performing its operational activities, a bank has several risks. One of these risks is the risk of problematic return of financing in sharia banking. This ratio is usually measured using Capital Adequacy Ratio (CAR) that represents the level of a bank's risky assets. These assets include securities, bills at other banks and financing receivables that are given to the public. CAR ratio can measure the capital adequacy to cover the risk of loss that may arise from bank operational activities. If a bank has adequate capital, the opportunity to gain profitability is higher, thus, it will cover the risk borne by the bank.

Similar to the conventional banks, sharia banks also provide more diverse services and do not use interest-based, but implement the profit and loss sharing (PLS) principle. Profitsharing financing (PLS) distributed by dividing the profits and risk between bank and customers according to the agreement (Ascarya, 2011). Murabahah, musyarakah and mudharabah financing distributed by banks to customers might serve a large impact on the development of a bank. These financings earn profits for the banks. The profit can be seen from the profitability level measured using financial ratio. The higher the profit generated from financing result, the higher is the responsibility of sharia banks to disclose the social and environmental responsibility through Sustainability Reporting. 
Previous research that analyze the mudharabah and musyarakah profit sharing on profitability (ROE) is Rahayu, Husaini, \& Azizah, (2016). The study concludes that mudharabah financing has a positive effect on profitability (ROE), while musyarakah financing has a negative effect on profitability (ROE). Another study conducted by Wibowo \& Sunarto, (2015) which concludes that mudharabah and murabahah financing has a positive effect on ROE. Nasim \& Pravitasari (2005) find that murabahah has a negative effect on Non-Performing Financing (NPF). Further Ratri \& Dewi, (2017) in their study concludes that financial performance has a positive effect on Islamic Social Reporting (ISR) disclosure. Roziq \& Aburizal (2019) also conclude that profitability is a mediating variable on the effect of financing and cash on corporate social responsibility (CSR).

The review on previous studies indicates that there is a diverse result concerning the effect of financing type on financial performance. But the research that connected the Financing type with Sustainability reporting is rarely done, especially by adding financial performance as a mediating variable. Therefore, the difference of this study with previous studies is examining three proxies in the Financing type, murabahah, musyarakah, and mudharabah financing on Sustainability Reporting with financial performance proxied with Capital Adequacy Ratio (CAR) as a mediating variable.

According to Freeman (1984), stakeholder is not only consist of stockholders but also has larger constituents such as the environment and the wide community. Clakson (1995, dalam Freeman (1984) divided stakeholder into three categories: first, the stakeholder is the person who can claim ownership, right, with past, current, and future activities, including employees and customers. The second group is the primary stakeholder, that is the potential investor and shareholders, while the third group is the secondary stakeholder who influences or get influenced by the firm but is not involved in the firm's activities, such as the community and media that can stir public opinion.

According to Freeman (1984), stakeholder theory assumes that a firm needs to show its responsibility in terms of accountability and responsibility to make people become attached and pay more attention to the firm. Stakeholder theory in the Islamic perspective explains that there are obligations and responsibilities that each person bears to implement their obedience to the God, the human task as caliph in the earth to protect the earth, environment, and community which is the implicit contract between human and God (Iqbal and Molyneux, 2005). When human experiences failure in achieving their obedience, it means that they have betrayed God and receive the consequence in the world and hereafter. When a community move together, any conflicts can be minimized and they will be able to form a unity. The community will no longer compete with each other but will help each other according to the word of Allah in Q.S ashShaff (61) 4. In this perspective, Islamic Stakeholder Theory underlies the company's activities in preparing Sustainability Reporting.

Sustainability reporting (SR) is a publication of a report that present the organizational values and governance model, as well as showing the relationship between business strategy and commitment to the global sustainable global economy. SR covers three aspects of the disclosure, namely environmental aspect, social aspect, and economic aspect (GRI, 2018). The Sustainability Reporting for sharia-based business currently uses Islamic Social Reporting (ISR) which contains several indicators, among others financing and investment indicator, product and service, employees, community, environment, and corporate governance (Othman, Thani, \& Ghani, 2009).

Financing is a fund provided by a party for other parties to support the investment that has been planned, both performed by an individual or institution. Financing in sharia banking refers to the interest-free principle and Islamic sharia according to al-Quran and al-Hadist. Musyarakah according to Law Number 21 of 2008 concerning sharia banks article 19 paragraph 1, point $\mathrm{c}$ is a cooperation agreement between two or more parties for a certain business in which each party provides a portion of funds provided that the profits will be divided according to the agreement, 
while losses are borne per the portion of their respective funds (ariyani, 2014). Mudharabah according to Law Number 21 of 2008 concerning sharia banks article 19 paragraph (11) point c is cooperation agreement for a certain business between the first party (malik, shahibul mal, or sharia bank) who provide all capitals and the second part ('amil, mudharib, or customer) who act as the manager of the fund by dividing the profit according to the agreement, while losses are fully borne by sharia bank except if the second party perform intentional error, neglect or violate the agreement (ariyani, 2014). Murabahah contract according to Law Number 21 of 2008 concerning sharia banks article 19 paragraph (1) point $\mathrm{c}$ is financing agreement for an item by stating the purchasing price to the buyer and buyer pay with a higher price as an agreed profit.

Research on the effect of financing types on sustainability reporting has not been done much by previous studies. However, referring to previous research by Masrurroh \& Mulazid (2017), there is an influence of financial performance represented by the Capital Adequacy Ratio and Non-Performing Financing on sustainability reporting. Also, previous studies by Wibowo \& Sunarto (2015), Rahayu, Husaini, \& Azizah (2016), Ernayani \& Robiyanto (2019) showed the results that Islamic financing which included murabahah, musyaraah and mudharabah was able to encourage financial performance.

Financial performance is a representation of financial condition in a firm during a certain period that includes various aspects such as the aspect of fundraising and fund distribution which usually measured through the indicators of capital adequacy, liquidity, and profitability (Jumingan, 2006). Bank Indonesia determines the regulation on Bank health in Bank Indonesia Decree Number 9/1/PBI/2007 concerning bank financial performance that can be observed from various aspects using CAMEL. CAMEL is ratios that consist of Return on Assets (ROA), Capital Adequacy Ratio (CAR), Non-Performing Financing (NPF), Operational Cost Operating Income (BOPO), Net Operating Margin (NOM), Financing to Deposit Ratio (FDR), and Third's Party Fund (DPK). Referring to the results of the previous research, it indicates that there is a related relationship between financing type, financial performance, and sustainability reporting. This study aims to determine the effect of financing type on sustainability reporting with financial performance as a mediating variable. In this study financial performance is measured using CAR which is a ratio to assess a bank's ability in managing its capital and control the risk which appears and affect a bank's capital. Capital Adequacy Ratio is a ratio of capital adequacy which is related to the anticipation of risk of loss that arises from the operational activities. Sharia banks with high CAR shows a high ability of financial resource that can be used in business development and anticipate the potential of loss caused by financing activities.

\section{Financing Type and Financial Performance}

According to Wibowo \& Sunarto (2015), a bank has a function to raise funds and redistribute it for activities that generate profit. One of the means to distribute the funds to the customers is murabahah, musyarakah, and mudharabah financing. These financings will generate profit from the profit-sharing calculation. This profit will be divided between bank and customers as profit sharing of funds invested in Islamic banks. On the other hand, for sharia bank, a portion of the profits will be used to increase the distribution of funding in the current period.

The distribution of murabahah, musyarakah, and mudharabah financing is expected to provide benefits to sharia banking so that the performance from the financing will affect sharia banking profitability. From the Islamic stakeholder Theory, when a sharia bank gains trust from its stakeholder, its customers will invest their funds through the potential financings which are expected to increase the profitability. Because of that, sharia banks with a high level of financing type will have an opportunity to get high profitability. This is in line with the study conducted by Rahayu, Husaini, \& Azizah (2016) and Wibowo \& Sunarto (2015), which find that high financing type will affect financial performance.

Murabahah financing will generate income in the form of margin/mark up. According to the Islamic stakeholder Theory, the concept of markup creates stable profit from the financing and 
lower risk compared to other types of financing within a certain period. However, this financing type has a higher risk for the long-term period. The ease of management makes it possible for sharia banks to increase its ability in generating profits, thus, the higher the murabahah financing, the higher is the margin or profit generated, following stakeholder's expectation. Next, the result of a study conducted by Fadhila, (2015), states that murabahah financing affects profitability, therefore, the hypothesis that will be tested in this study is:

$\mathrm{H}_{1}$ : Murabahah financing affects financial performance

Musyarakah financing is an agreement between two or more capital owners to finance a business. The determination of profit sharing nisbah is conducted based on musyarakah and divided according to the agreement in the contract (Fahrul, 2012). In line with the Islamic stakeholder Theory, musyarakah financing allows for higher yields compared to other PLS contracts, so it is expected to increase profitability, and fulfil stakeholder expectations. The result of a study conducted by Rahayu, Husaini, \& Azizah, (2016) and Wibowo \& Sunarto, (2015), conclude that musyarakah financing has positive effect on profitability. The larger the portion of Musyarakah financing, the higher is the level of profitability that can be achieved, thus, the hypothesis that will be tested is:

\section{$\mathrm{H}_{2}$ : Musyarakah financing affects financial performance}

Mudharabah financing uses profit-loss sharing method that allows for the greater risk borne by the bank due to customer losses. Islamic stakeholder Theory states that the responsibility on the loss in Mudharabah financing will be bear by the sharia bank, therefore, high mudharabah financing will increase risks, which in turn will affect profitability. The level of profitability will affect stakeholder in taking an investment decision on sharia banks. The result of a study conducted by Rahayu, Husaini, \& Azizah, (2016) and Wibowo \& Sunarto, (2015), conclude that mudharabah financing affects profitability, thus, the hypothesis tested in this study is:

\section{$\mathrm{H}_{3}$ : Mudharabah financing affects financial performance.}

\section{Financial Performance and Sustainability Reporting}

Islamic stakeholder Theory explains that a firm will pay attention to the resources it owned before making a decision. The level of financial performance will have a broad effect on the community. The higher the profitability generated by a firm, the higher is information that they have to disclose to their stakeholder. One of the information that has to be disclosed is Sustainability Reporting. The previous study states that financial performance (CAR, NPF, ROA, and FDR) simultaneously affect the Sustainability Reporting (Masrurroh \& Mulazid, 2017). CAR can affect the level of profitability of sharia banks. High CAR creates free and flexible management which will perform social responsibility to the stakeholder. Additionally, a firm with high profitability will provide discretion for management to implement their environmental responsibility, thus, high firm's performance will motivate management to prepare SR.

$\mathrm{H}_{4}$ : Financial performance has a significant effect on Sustainability Reporting.

\section{The Effect of Financing Type on Sustainability Reporting with Financial Performance as a Mediating Variable}

The effect of Financing Type (murabahah, musyarakah and mudharabah) on Sustainability Reporting is under-researched. However, the result of several previous studies concludes that Financing Type has a direct effect on financial performance, and financial performance has a direct effect on Sustainability Reporting. Thus, financial performance is used as a mediating variable in the relationship between Financing Type on Sustainability Reporting.

From Islamic Stakeholder Theory, the higher the murabahah financing, the lower is the 
risk, thus, allowing sharia banks to increase its profitability. Further, the higher the profitability, the higher is the opportunity to set a budget for social and environmental activities required by the stakeholder. Roziq \& Aburizal (2019) conclude that high murabahah financing can affect the disclosure of social responsibility. Thus, stakeholder including customers who entrust their funds needs transparency of disclosure through Sustainability Reporting. It can be said that the higher the Murabahah financing, the broader is the information presented in SR, because of budget allocations originating from profitability allowance. Therefore, the hypothesis that will be tested in this study is:

\section{$\mathrm{H}_{5}$ : Murabahah financing has a significant effect on Sustainability Reporting mediated by finan-} cial performance.

Roziq \& Aburizal (2019) find that musyarakah financing affects sustainability reporting. Musyarakah financing according to Islamic Stakeholder Theory has low risk but allow for an opportunity to generate higher profit sharing. The higher the profit-sharing level, the higher is the opportunity for a firm to set aside profit, so that it can publish sustainability reporting as a responsibility to its stakeholder. Therefore, the hypothesis tested in this study is:

$\mathrm{H}_{6}$ : Musyarakah financing has a significant effect on Sustainability Reporting with performance as a mediating variable.

Mudharabah financing has a higher risk because the loss will be fully borne by a bank if the loss occurs is not a negligence of the customer. Roziq \& Aburizal (2019) stated that mudharabah financing affects sustainability reporting. Further, in the Islamic stakeholder Theory perspective, the higher the level of mudharabah financing, the higher is the risk that must be borne by sharia bank, thus, making it harder to report the responsibility to the stakeholder. However, mudharabah financing also allows sharia bank to get high financial performance if the financing is distributed to a trustworthy and professional customer. The allocation of profit-sharing funds from mudharabah financing activity allows sharia banks to prepare a Sustainability Reporting, thus, the hypothesis tested is:

\section{$\mathrm{H}_{7}$ : Musyarakah financing has a significant effect on Sustainability Reporting with performance as a mediating variable.}

\section{METHOD}

\section{Population, Sample, and Research Data}

This study aims to test the effect of Financing Type mediated by Financial Performance on Sustainability Reporting, using a quantitative method. The object studied in this study is sharia banks listed in OJK per 2019. The data analyzed is secondary data from the firm's annual report and sustainability report downloaded from the website of each firm. The method used to analyze the data is structural equation modelling using STATA 13.

The population in this study is the sharia Islamic banks listed in the Financial Service Authority (OJK) during 2014-2017. The samples in this study are selected using purposive sampling with the following criteria:

1. Sharia banks listed in OJK statistics during 20142017.

2. The firm publishes Sustainability Reporting and or annual report in 2014-2017.

3. The firm publishes complete data on the variables used in this study

4. According to the statistical data of sharia banks published by Otoritas Jasa Keuangan per June 2019 , the total number of sharia banks in Indonesia is 14 banks, and 14 banks have published a complete Annual Report for the research period. The source of data for this study is the Annual Report from 2014 to 2017. The initial samples of this study are 56 annual reports. 
Table 1. The Number and Classification of Research Samples

\begin{tabular}{llc}
\hline No & \multicolumn{1}{c}{ Classification } & Total \\
\hline 1 & Annual report of sharia commercial banks listed in OJK in 2014-2017 & 56 \\
2 & $\begin{array}{l}\text { Annual report of sharia commercial banks that do not disclose all research vari- } \\
\text { ables (incomplete data) }\end{array}$ \\
3. & Outlier & $(2)$ \\
\hline & Total & 39 \\
\hline
\end{tabular}

Source: Processed data (2019)

\section{Sustainability Reporting}

Sustainability Reporting is measured using Islamic Social Reporting (ISR)index developed by Haniffa (2002) and Othman et al. (2009) with six indicators that consist of 48 disclosure items adjusted to AAOIFI guidelines. ISR indicators are classified into six disclosure themes: 1) Financing and investment; 2) Products and services; 3) Employees; 4) Communities; 5) Environment; and 6) Corporate governance. The variable is measured using the scoring method. Score 1 is given for the item disclosed according to ISR index and score 0 is given for the undisclosed item. The measurement results are expressed with values that can be calculated based on simple calculations

$\mathrm{SR}=\frac{\text { Total score obtained }}{\text { The maximum score that can be obtained }}$

\section{Financing Type}

This study employs three financing types, murabahah, musyarakah, and mudharabah.

1. Murabahah Financing

Murabahah financing is measured by dividing the total murabahah financing to the total of financing

Murabahah $=\frac{\text { Total Murabahah Financing }}{\text { Total Financing }}$

2. Musyarakah Financing

Musyarakah financing is measured by dividing the total musyarakah financing to the total financing.

$$
\text { Musyarakah }=\frac{\text { Total Musyarakah Financing }}{\text { Total Financing }}
$$

3. Mudharabah Financing

Mudharabah financing is measured by dividing the total mudharabah financing to the total financing.

$$
\text { Mudharabah }=\frac{\text { Total Mudharabah Financing }}{\text { Total Financing }}
$$

\section{Financial Performance}

Financial performance in this study is measured using the CAR calculated using the following formula:

$$
C A R=\frac{\text { Stock Holder Equity }}{\text { Total Risk Weight Assets (ATMR) }}
$$

\section{RESEARCH METHOD}

The analysis techniques used in this study are descriptive statistics, correlation matrix analysis, structural equation modelling analysis.

Structural Equation: 


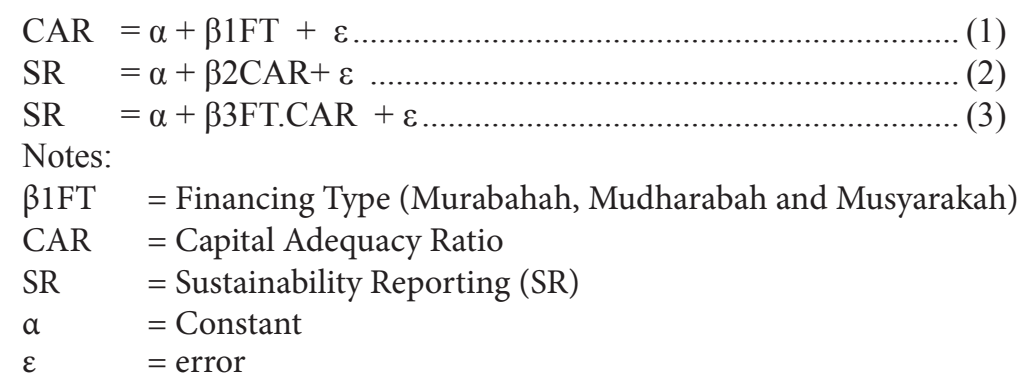

\section{RESULT AND DISCUSSION}

\section{Descriptive Statistics Test}

Table 2. The Result of Descriptive Statistics Analysis

\begin{tabular}{lccccc}
\hline \multicolumn{1}{c}{ Variable } & Obs & Mean & Std. Dev & Min & Max \\
\hline SR & 39 & 0.4563008 & 0.1273868 & 0.2195122 & 0.7317073 \\
Murabahah & 39 & 0.8969933 & 0.0013511 & 0.7991518 & 1 \\
Mudharabah & 39 & 0.0056636 & 0.0196828 & 0.0016639 & 0.0920876 \\
Musyarakah & 39 & 0.0053427 & 0.0023080 & 0.0001371 & 0.0748782 \\
CAR & 39 & 0.2215231 & 0.1307022 & 0.1151 & 0.7583 \\
\hline
\end{tabular}

Source: Processed Secondary Data, 2019

The descriptive statistics is the description of data from all variables in the study. Table 2 shows that the number of observations analyzed in this study is 39 data. The Financing Type variable proxied using murabahah financing has a mean score of 0.89 . This means murabahah financing distributed sharia banks in Indonesia is $89 \%$, while the remaining financings are distributed as Mudharabah financing with $5.6 \%$ and musyarakah financing with $5.3 \%$. Financial performance proxied using CAR has a mean score of 0.12 , which means the average capital adequacy ratio of sharia banks in Indonesia is $12 \%$ with a standard deviation of $3 \%$. The SR variable has the mean score of 0.45 , this means in average, the information conveyed in the sustainability report is $45 \%$ with a standard deviation of $12 \%$. This indicates that the indicator disclosed in the Sustainability Reporting of sharia bank in Indonesia is quite good.

Correlation Matrix Analysis

Table 3. Matrix Correlation Result

\begin{tabular}{lllll}
\hline & Mura & Mudha & Musya & CAR \\
\hline Mura & 1 & & & \\
Mudha & 0.0906 & 1 & & \\
Musya & 0.1570 & 0.1355 & 1 & \\
CAR & 0.3467 & 0.0216 & 0.2456 & 1.0000 \\
\hline
\end{tabular}

Source: Processed Secondary Data, 2019

Table 3 shows the result of the correlation matrix, we can see that there is no strong correlation among the variables because the relationships are $<0.75$. Therefore, the variables in this study can be analyzed simultaneously.

\section{Regression Analysis}

Table 4 shows the score of adjusted $\mathrm{R}^{2}$ for each test, the $\mathrm{R}^{2}$ for CAR is 0.145 which means $14.5 \%$ of the variance in the dependent variable can be explained by the independent variable. While the rest, $85.5 \%$ of the variance is explained by another variable which is not included in the regression model. The adjusted $\mathrm{R}^{2}$ score for the dependent variable $\mathrm{SR}$ is 0.328 which means the variability of the variable explained is $32.8 \%$, while the rest $61.2 \%$ is explained by another 
variable. Table 4 also compute the overall $\mathrm{R}^{2}$ for this research model, which is 0.217 This means that the variability explained by the independent variables in this study is $21.7 \%$ and the rest $78.3 \%$ is explained by another variable.

Table 4. Direct Effect Result of Structural Equation Modeling

\begin{tabular}{|c|c|c|c|c|}
\hline & Coef. & Err. & $\mathrm{Z}$ & $\mathrm{P}>\mathrm{Z}$ \\
\hline \multicolumn{5}{|l|}{ Structural } \\
\hline \multicolumn{5}{|l|}{ CAR <- } \\
\hline murabahah & -3.195741 & 0.5450888 & -5.86 & $0.000^{* * *}$ \\
\hline mudharabah & 0.0569758 & 0.0460354 & 1.24 & 0.216 \\
\hline musyarakah & -0.0766319 & 0.0566444 & -1.35 & 0.176 \\
\hline \multicolumn{5}{|c|}{ Adj. $\mathrm{R}^{2} \quad 0.1458681$} \\
\hline \multicolumn{5}{|l|}{$\mathrm{SR}<-$} \\
\hline CAR & -0.4346021 & 0.1111381 & -3.91 & $0.000^{* * *}$ \\
\hline murabahah & 0.7152048 & 0.4229668 & 1.69 & $0.091^{\star}$ \\
\hline mudharabah & -0.1119967 & 0.0735295 & -1.52 & 0.128 \\
\hline musyarakah & 0.1079366 & 0.0592122 & 1.82 & $0.068^{\star}$ \\
\hline \multicolumn{5}{|c|}{ Adj. $\mathrm{R}^{2} \quad 0.3284027$} \\
\hline Overall Adj. $\mathrm{R}^{2}$ & 0.2177423 & & & \\
\hline
\end{tabular}

Source: Processed Secondary Data, 2019

Table 4 shows the result of the direct effect of Financing Type on financial performance and Financing Type, financial performance on Sustainability Reporting. The p-value of Murabahah, Mudharabah and Musyarakah financing on CAR is 0.000, 0.216, and 0.176. This shows that only Murabahah financing affects financial performance with the significance level of $1 \%$ and Mudharabah, Musyarakah financing have the greater singnification level of 0.10 , so it can be concluded that the Mudharabah, Musyarakah financing has no effect on CAR. This means that the first hypothesis (H1) which test the significant effect of Murabahah financing on CAR is supported but the second (H2) and third (H3) hypothesis which test the significant effect of Mudharabah and Musyarakah financing on CAR is not supported.

Table 4 also shows the result of the direct effect of financial performance on Sustainability Reporting. The P-Value of CAR variable is 0.000 , significant at $1 \%$, this shows that CAR affects the area of Sustainability Reporting, this means that the fourth hypothesis (H4) which test the significant effect of CAR on SR disclosure is supported.

Then, table 4 also shows the direct effect of Financing Type variable on Sustainability Reporting. The P-value of Murabahah and Musyarakah on SR is 0.091 , and 0.068 or significant at the $10 \%$ level. This result concludes that Murabahah and Musyarakah financing affects Sustainability Reporting with the level of significance of $10 \%$. The p-value of Mudharabah financing on SR is 0.128 , Mudharabah financing have the greater singnification level of 0.10 , so it can be concluded that the Mudharabah financing has no effect on SR.

Table 5. The Result of Path Analysis and Sobel

\begin{tabular}{llllllr}
\hline \multicolumn{1}{c}{ Variable } & Direct Effect & Sig. & Indirect Effect & t-count & Sig. \\
\hline 1. & Murabahah on CAR & -3.195 & Yes & 1.386 & 4.465 & Yes \\
& CAR on SR & -0.434 & Yes & & & \\
2. & Mudharabah on CAR & 0.056 & No & -0.024 & No \\
& CAR on SR & -0.434 & Yes & & 0.027 & No \\
3. & Musyarakah on CAR & -0.076 & No & 0.032 & & \\
& CAR on SR & -0.434 & Yes & & & \\
\hline
\end{tabular}

t-table: 2.030 (estimasi TINV[0.05, Degrees of Freedom])

Source: Processed Secondary Data, 2019 
Table 5 shows the result of sobel analysis on the effect of Financing Type on Sustainability Reporting through financial performance. The p-value of indirect effect of Murabahah financing on SR through CAR in level 5\% significance and shows a coefficient score of 1.386, which indicates that Murabahah financing has a significant effect on sustainability reporting through CAR. The p-value of Mudharabah and Musyarakah financing has a p-value of more than $10 \%$ which means that Mudharabah, Musyarakah financing has no effect on SR through CAR.

\section{Regression Discussion}

The direct effect of Financing Type on financial performance based on table 4 showed that, Murabahah financing affects financial performance with the significance level of $1 \%$. The result of this study is consistent with the research conducted by Fadhila, (2015). But the beta coefficient shows a negative $(-3.195)$ effect, which means the high Murabahah financing will reduce financial performance. Hypothesis 2 and 3 are not supported because both Musyarakah and Mudharanah financing do not affect financial performance. This finding is not consistent with the study conducted by Wibowo \& Sunarto, (2015) and Rahayu, Husaini, \& Azizah, (2016), (Hendrik, 2018), and (Agustin, Hariswanto, \& Bustamam, 2018) which conclude that Musyarakah and Mudharabah financing affect financial performance. The difference in the finding might be caused by the difference of proxies used to measure financial performance. Further, it can be explained that Musyarakah and Mudharabah financing have a high risk because both financing are based on Profit Loss Sharing (PLS) which highly related to the level of profit or loss generated from the financing. Additionally, if there is moral hazard in the lack of transparency of earning submitted by customer in Musyarakah and Mudharabah financing.

The result of the direct effect of financial performance on Sustainability Reporting based on table 4 showed that, CAR affects financial performance with the significance level at $1 \%$, this shows that CAR affects the area of Sustainability Reporting. This finding is consistent with the study conducted by (Ratri \& Dewi, 2017) which concludes that financial performance affects Sustainability Reporting. But the beta coefficient shows a negative score, which means that the higher the financial performance the less information in Sustainability Reporting is disclosed to the public. This might be caused by the measurement of financial performance using CAR as a proxy with stockholder equity. This measurement results in the negative score because the proxy represents the values owned by stockholders as of the party who has no direct interest in social information contained in Sustainability Reporting. Thus, Stockholder equity does not require broader information disclosed in the Sustainability Reporting.

The direct effect of Financing Type variable on Sustainability Reporting showed that Murabahah and Musyarakah financing affects Sustainability Reporting with thelevel of significance of $10 \%$, which means that the higher the Murabahah and Musyarakah financing, the broader and extensive the information disclosed in Sustainability Reporting. This result is consistent with the result of a study conducted by Roziq \& Aburizal (2019) which find that Murabahah and Musyarakah financing affect Sustainability Reporting. Murabahah financing based on margin enables sharia banks to get a more stable profit, thus, having a resource (reserves fund) that can be used to deliver broader Sustainability Reporting information. Similarly, Musyarakah financing based on PLS allows the amount of profit that can be used for the formation of reserves fund to deliver broader information in Sustainability Reporting.

The result of the path and Sobel analysis on the effect of Financing Type on Sustainability Reporting through financial performance. The indirect effect of Murabahah on SR through CAR shows a score of 1.386 while the score of the direct coefficient for the effect of Murabahah on SR is 0.715 (table 5). This means that the score of path coefficient for the indirect effect of Murabahah on SR is larger than the direct coefficient $(1.386>0.715)$. Besides that, from the Sobel test, we acquired a $\mathrm{t}$-count score of 4.465 , while the $\mathrm{t}$-table with the significance level of $5 \%$ is 2.030 , therefore, we can conclude that CAR has a role as a mediating variable on the effect of murabahah on SR. The result of this study is consistent with the study conducted by Ahmad Roziq \& Ibnu 
Aburizal, 2019 that the higher the level of Murabahah financing the broader is the information disclosed in the Sustainability Reporting when the financial performance is positive.

The coefficient of the indirect effect of Mudharabah on SR is -0.024 , while the coefficient of direct effect is -0.111 (Table 4$)$. The indirect effect is lower than the direct effect $(0.024<0.111)$, thus, CAR does not act as a mediating variable. This is strengthened by the $t$-count score that is lower than the t-table $(0.027<2.030)$. The Mudharabah financing has not widely implemented in sharia banks, this might be due to the risk of the financing type and the lack of readiness of Islamic banks in managing the distribution of Mudharabah financing. Profit generated by the bank as shahibul maal depends on the success of the customer's business because of the profit and loss sharing principle (Putri, 2017). The lack distribution of mudharabah financing reduces one of the sources of profit for a bank which causes less optimal performance and has an impact on reducing the existence of banks through sustainability reporting.

The indirect effect of musyarakah on sustainability reporting shows a coefficient score of 0.032 , while the coefficient of the direct impact is 0.107 (table 5). This means the coefficient score of indirect effect is lower than the direct impact $(0.032<0.107)$, thus, CAR cannot mediate the effect of musyarakah financing on sustainability reporting. This result is strengthened by the t-count score which is lower than the $t$-table score $(0.041<2.030)$. Musyarakah financing is the same with Mudharabah financing that it has the loss and profit-sharing principle, but the investment is not limited to funds, but also other items that can be valued in money. The risk from the principle causes sharia bank to not be able to maximize the level of distribution of musyarakah financing (Agza \& Darwanto, 2017), thus, affect bank profitability as a measure of financial performance and sustainability reporting.

\section{CONCLUSION}

Overall, this study concludes that Financing Type proxied with Murabahah affects Financial Performance (CAR) and Financial Performance (CAR) also affects Sustainability Reporting. The other proxies of Financing type (Musyarakah and Mudharabah) do not affect Financial Performance. The result of this study also concludes that financial performance mediates the effect of Financing type (Murabahah) on Sustainability Reporting.

This study has several limitations, namely, the measurement of Sustainability Reporting using a score based on Islamic Social Reporting (ISR) with very limited items, and only use one proxy of financial performance. Besides that, this study also uses a limited number of observations and a short observation period. Therefore, the suggestion for the future study is to use a different measurement of Sustainability Reporting and different and more diverse proxies of financial. The scope of research can also be expanded and the research period can be extended.

\section{REFERENCES}

AAOFII. 2010, Corporate Social Responsibility Conduct and Disclosure for Islamic Financial Institutions. Accounting and Auditing Organization for Islamic Financial Institutions

Agustin, H., Hariswanto, H., \& Bustamam, N. (2018). the Effect of Non Performing Financing Mudharabah and Musyarakah and Ownership of Banks on the Profitability of Sharia Banks. Jurnal Tabarru': Islamic Banking and Finance, 1(2), 33. https://doi.org/10.25299/jtb.2018.vol1(2).2814

Agza, Y., \& Darwanto, D. (2017). Pengaruh Pembiayaan Murabahah, Musyarakah, Dan Biaya Transaksi Terhadap Profitabilitas Bank Pembiayaan Rakyat Syariah. Iqtishadia: Jurnal Kajian Ekonomi Dan Bisnis Islam STAIN Kudus, 10(1), 228-248.

Antonio, muhammad S. (2001). Bank Syariah Dari Teori ke Praktik. Jakarta: Gema Insani Press.

Arim Nasim \& Cahyawati Ayu Pravitasari. (2005). Pengaruh Pemberian Pembiayaan Murabahah terhadap Non Performing Financing pada Bank Umum Syariah di Indonesia. Jurnal Akuntansi Riset, Prodi Akuntansi UPI, 1, 235-246.

Ascarya. (2011). Akad dan Produk Bank Syariah. Jakarta: PT Raja Grafindo Persada.

Bellucci, M., Manetti, G., \& Thorne, L. (2018). Stakeholder Engagement and Sustainability Reporting. In Stakeholder Engagement and Sustainability Reporting. https://doi.org/10.4324/9781351243957 
Dewi, R. K., Widagdo, B., \& Malang, U. M. (2003). Pengaruh Corporate Social Responsibility Dan Good. (1994), 81-98.

Ernest and Young. (2017). The Rise of Sustainability-Reporting in Indonesia.

Ernayani, R., \& Robiyanto, R. (2019). Funding Analysis Of Murabahah, Musyarakah, And Mudharabah On Return On Asset On Sharia Banks In Indonesia. Jurnal Dinamika Ekonomi Dan Bisnis, 16(2).

Freeman, R. E. (1984). Strategic Management: A Stakeholder Approach. Boston Pitman.

GRI. (2018). About Sustainability Reporting.

Haniffa, R. (2002). Social Reporting Disclosure an Islamic Perspective. Indonesian Management \& Accounting Research, 1(2), 128-146.

Hendrik, S. (2018). Evidence From Indonesia: Is It True That Mudharabah Financing And Micro Business Financing Are At High Risk For Sharia Banking Business? Rjoas, 6(June), 197-205.

Jumingan. (2006). Analisis Laporan Keuangan. Jakrta: PT. Bumi Aksara.

Maali, B., Casson, P., \& Napier, C. (2006). Social reporting by islamic banks | ReadCube Articles. Abacus, 42(2), 266-289. https://doi.org/10.1111/j.1468-4497.2006.00200.x

Masrurroh, D. A., \& Mulazid, A. S. (2017). Analisa Pengaruh Size Perusahaan, Capital Adequacy Ratio ( Car ), Non Perfoming Financing ( Npf ), Return On Asset ( Roa ), Financing Deposit Ratio ( Fdr ) Terhadap Pengungkapan Corporate Social Responsibility ( Csr ) Bank Umum Syariah Di Indonesia Perio. Fakultas Ekonomi Dan Bisnis, 4(1).

Muhamad, R., \& Noordin, K. (2014). Corporate social responsibility disclosure : a tawhidic approach Corporate Social Responsibility, Corporate Financial Performance and Institutional Ownership : Evidence from. 3(January 1970), 1-13.

Munawar Iqbal and Philip Molyneux. (2005). Thirty Years of Islamic Banking: History, Performance and Prospects.

NCSRID. (2015). sustainability reporting 2015.

Othman, R., Thani, A. M., \& Ghani, E. K. (2009). Determinants Of Islamic Social Reporting Among Top Shariah -Approved Companies In Bursa Malaysia. Research Journal of International Studies, 12(12), $4-20$.

Otoritas Jasa Keuangan, Praktis, M., Prinsip, D., Berkelanjutan, K., Program, P., Berkelanjutan, K., ... Berkelanjutan, P. K. (2018). Pedoman Teknis Bank Tentang Penerapan Laporan Keuangan Berkelanjutan Bagi LJK, Emiten, dan Perusahaan Publik.

Putri, F. L. (2017). Pengaruh Pembiayaan Mudharabah Terhadap Profitabilitas Bank Syariah. Jurnal Pendidikan Akuntansi \& Keuangan, 5(1), 11. https://doi.org/10.17509/jpak.v5i1.15384

R Edward Freeman and David. (1983). Stockholders and Stakeholders: A New Perspective on Corporate Governance. California Management Review, 25. https://doi.org/10.5897/ajmr2014.7057

Rahayu, Y. S., Husaini, A., \& Azizah, D. F. (2016). Pengaruh Pembiayaan Bagi Hasil Mudharabah Dan Musyarakah Terhadap Profitabilitas (Studi pada Bank Umum Syariah yang terdaftar pada Bursa Efek Indonesia periode 2011-2014). Jurnal Administrasi Bisnis S1 Universitas Brawijaya, 33(1), 6168.

Ratri, R. F., \& Dewi, M. (2017). The Effect of Financial Performance and Environmental Performance on Firm Value with Islamic Social Reporting (ISR) Disclosure as Intervening Variable in Companies Listed at Jakarta Islamic Index (JII). SHS Web of Conferences, 34, 12003. https://doi.org/10.1051/ shsconf/20173412003

Roziq. Ahmad \& Aburizal, Ibnu (2019). Pengaruh Pembiayaan Dan Kas Terhadap Corporate Social Responsibility Melalui Laba Sebagai Variabel Intervening Pada Bank Umum Syariah Di Indonesia. Jurnal Akuntansi Universitas Jember, 1-11.

the Association of Chartered Certified. (2014). Sustainability matters, ACCA Policy paper. 20.

Wibowo, A., \& Sunarto. (2015). Pengaruh Pembiayaan Mudharabah Dan Musyarakah Terhadap Profitabilitas Perbankan Syariah (Studi Kasus Pada Bank Pembiayaan Rakyat Syariah Daerah Istimewa Yogyakarta Yang Terdaftar Di Bank Indonesia Periode 2012-2014). Seminar Nasional Dan The 3rd Call for Syariah Paper, 115-124.

Worldbank. (2015). Islamic Finance. 